\title{
Potentiality of Ethanol as a Fuel for Dedicated Engine*
}

\author{
N. Jeuland ${ }^{1}$, X. Montagne ${ }^{1}$ and X. Gautrot ${ }^{1}$ \\ 1 Institut français du pétrole, 1 et 4, avenue de Bois-Préau, 92852 Rueil-Malmaison Cedex - France \\ e-mail: nicolas.jeuland@ifp.fr - xavier.montagne@iff.fr - xavier.gautroł@ifp.fr \\ * From the conference proceedings "Which Fuels For Low- $\mathrm{CO}_{2}$ Engines?" published in full by Éditions Technip
}

Résumé - Potentiel de l'éthanol en tant que carburant pour un moteur dédié — Un des défis majeurs de l'industrie automobile est de réduire les émissions de gaz à effet de serre et, en particulier, celles du $\mathrm{CO}_{2}$. Plusieurs programmes de recherche sont en cours sur ce sujet, visant la réduction de la consommation des véhicules, mais aussi l'optimisation de la composition des carburants. Il est en effet essentiel de prendre en compte l'ensemble du processus, de la production des carburants aux émissions des véhicules, et un bilan "du puits à la roue" doit être effectué pour chaque technologie.

L'éthanol possède des atouts importants pour satisfaire ces nouvelles contraintes : étant extrait de la biomasse, son bilan d'émission du $\mathrm{CO}_{2}$ "du puits à la roue" est favorable. De plus, ses propriétés, en particulier en termes d'indice d'octane et de chaleur latente de vaporisation, permettent une optimisation du fonctionnement du moteur.

La présente étude a pour but d'évaluer la voie éthanol. Les moyens de production sont considérés, en particulier leur bilan énergétique. Les principaux avantages et inconvénients de l'utilisation d'un tel carburant sont résumés. Enfin, nous présentons un exemple des gains qui peuvent être réalisés en optimisant un moteur pour l'utilisation de l'éthanol pur. Un moteur suralimenté de petite cylindrée a en effet été optimisé afin de bénéficier du potentiel de l'éthanol, notamment en termes de réduction du cliquetis. Les performances de ce moteur sont comparées à celles du moteur initial à essence, démontrant que des gains importants peuvent être obtenus avec une telle technologie.

\footnotetext{
Abstract - Potentiality of Ethanol as a Fuel for Dedicated Engine - One of the major challenges of the automotive industry is to reduce the greenhouse gases, and especially $\mathrm{CO}_{2}$ emissions. Many research programs are currently being led on this subject, aiming at reducing the fuel consumption of vehicles, but also at optimizing the fuel composition. The overall process must indeed be taken into account, from the fuel production to the vehicle emissions, and a "well to wheel" balance has to be calculated for each technology.

Ethanol seems to have important assets to comply with these new constraints: it is extracted from the biomass and consequently has a good "well to tank" $\mathrm{CO}_{2}$ emission balance. Moreover, its properties, especially in terms of octane number and latent heat of vaporization allow a large improvement of the engine.
} 
The present paper aims at taking stock of the ethanol path. The main production ways are tackled, especially concerning their energy balances. The main advantages and drawbacks of the use of such a fuel are then summarized. Finally, an example of the gains that can be obtained by an optimization of the engine using pure ethanol is presented. A small supercharged engine has already been modified to benefit from the potential of ethanol, especially in terms of knock resistance. The performances of this engine have been compared with those of the initial gasoline engine, showing that important gains can be obtained with such a technology.

\section{INTRODUCTION}

Ethanol as a fuel for internal combustion engines is not a new concept. Indeed, the first internal combustion engines and vehicles (N. Otto in 1877, H. Ford in 1880, in 1892 in France) were drawn to run with pure alcohol (methanol or ethanol). In the United States and also in many countries such as France or United Kingdom, many studies were achieved in the 1920's and 1930's with this fuel, before the wide diffusion of leaded gasoline induced a decrease in the interest in ethanol for years.

During the last decades, a renewed interest for ethanol has grown, linked with the more and more stringent emission limits. Moreover, some economical aspects, such as agricultural development (in Brazil for instance) have also favored to the use of ethanol. Finally, the Kyoto Protocol and the growing concern for greenhouse gas emissions will lead in the next coming years to an increase in biofuel productions, among which ethanol has an important role to play.

This paper presents the potentiality of the ethanol pathway as a fuel especially when used at very high concentration on a dedicated engine.

The potential of ethanol in a dedicated engine is described: the main advantages and drawbacks of this fuel are summarized and an example of application is given with the results obtained after a preliminary optimization of a small supercharged engine.

\section{USE OF ETHANOL IN THE WORLD}

Brazil is the largest user of ethanol as a fuel. It is the only country that uses ethanol blends at concentrations higher than $10 \%$, with the exception of the use of E85 in Flexible Fuelled Vehicles (FFV). Around 20\% of the Brazilian cars currently operate on $100 \%$ ethanol. The remaining cars are optimized to run on $22 \%$ blends (to meet the range of $20-24 \%$ blends). Brazil consumption of ethanol is around $15 \mathrm{Gl} / \mathrm{y}$.

In the United States, the US EPA regulates the use of $10 \%$ ethanol blends via the "Substantially Similar Rule" to ensure that the use of oxygenates does not contribute to emission control system failure. The regulation prohibits the introduction, or increase in concentration of a fuel or fuel additive which is not "substantially similar to any fuel or fuel additive already utilized". The Substantially Similar Rule recognizes that the use of certain types of oxygenates have no adverse effect below a specified oxygen content.

The US EPA regulations also create a process by which a waiver can be granted for an oxygenated "recipe" that is demonstrated not to cause or contribute to the failure of any emission control device or system. Under this regulation, the US EPA has granted waivers for concentrations of ethanol in petrol up to $10 \%$. The finished product has to pass gasoline specifications as defined by ASTM D 4814-88 and US original equipment manufacturer (OEM) vehicle warranties specify that petrol must contain no more than $10 \%$ ethanol. The use of blends higher than $10 \%$ in OEM vehicles could result in the void of vehicle warranties.

The US Department of Energy (under its Clean Cities Program) and the National Corn Growers Association are cooperating to promote the development of refueling infrastructure for E85 and to encourage fleet operators to choose ethanol to meet the alternatively fuelled vehicles requirements of the Energy Policy Act. As previously stated, E85 blends require FFV.

The potential phase-out of MTBE (methyl tert-butyl ether) and an increasing emphasis on domestic energy supplies and energy security are likely to favor in the United States the increased use of ethanol as a fuel.

In Europe, the ethanol content in gasoline is limited to $5 \%$ vol. ETBE is the preferred oxygenate by European refiners and car manufacturers.

\subsection{Ethanol Production Pathways}

Ethanol production for fuel is a combination of biological and physical processes. The main production process is the fermentation of sugars with yeast. Ethanol is then concentrated to fuel grade by distillation. The raw materials can be obtained from various types of crops, such as corn, wheat, sugar beet, etc.

Besides, some new ethanol production pathways appeared in the last years, producing ethanol from unconventional feedstock.

\subsection{Energy and Greenhouse Gas Balance}

The development of biofuels, and especially ethanol, is strongly linked to their environmental performances in terms 
of greenhouse gas (GHG) emissions and energy saving. To evaluate their efficiency, many studies focused on the "Analysis of Life Cycle" of each path (LCA).

The calculations show highly variable results, whose apparent discrepancies can be easily explained.

- As ethanol is produced from biomass, its energetic efficiency is strongly related to the raw material considered (corn, cellulose, etc.);

- Even when considering a single raw material type, the global efficiency is still strongly linked to the development of the production process (yield, agricultural techniques, use of fertilizers, etc.);

- Finally, the conversion rate of the raw material into ethanol can vary a lot.

The example of United States corn ethanol is very symptomatic of these difficulties: before 1990, some studies showed a negative energy balance for corn ethanol. Nevertheless, the increase in yields, shown in Figure 1, turned the energy balance to positive.

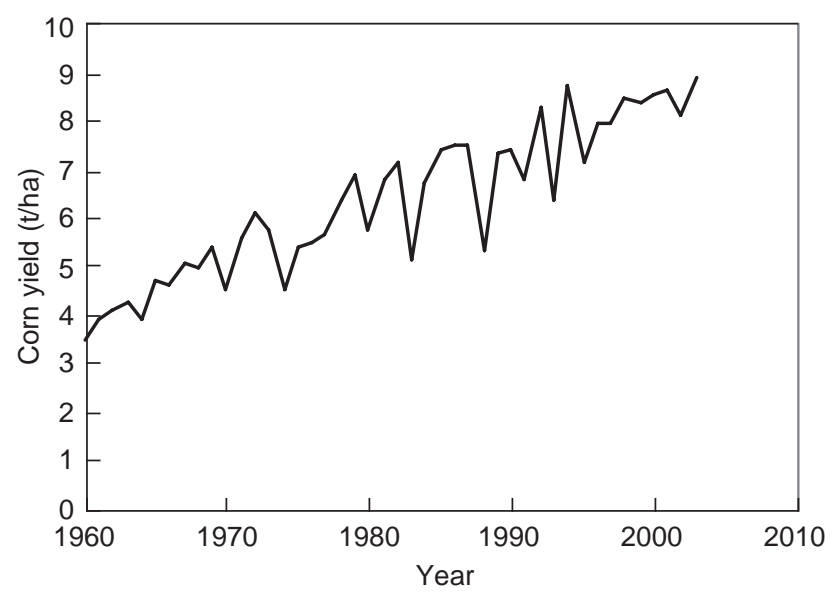

Figure 1

United States corn yield evolution [1].

TABLE 1

Ethanol yield (hl/ha) for various crops

\begin{tabular}{|c|c|c|c|c|c|c|c|c|}
\hline & [9] & {$[10]$} & [5] & [6] & [7] & {$[8]$} & [11] & Mean \\
\hline Barley & 7.7 & & & & & & & 7.7 \\
\hline Corn & 32.8 & & 17.3 & 18.2 & & & 19.1 & $21.8+/-7$ \\
\hline $\begin{array}{l}\text { Grain } \\
\text { sorghum } \\
\text { Wheat }\end{array}$ & $\begin{array}{c}5.4 \\
11.6\end{array}$ & 20.1 & & 17.4 & 19.5 & 13.0 & & $\begin{array}{c}5.4 \\
16.3+/-3\end{array}$ \\
\hline Beet & & 23.7 & & 47.4 & & 21.7 & & $30.9+/-16$ \\
\hline
\end{tabular}

Moreover, as described above, the ethanol production from the raw material is strongly linked to the raw material itself, and also to the development of the transformation industry itself. Table 1 summarizes the ethanol yields calculated in various studies.

In Europe, corn is not used for ethanol production. The most commonly used raw materials are wheat and beet (especially in France). As for corn ethanol in the United States, the energy balance and greenhouse gas balance are highly dependant on the agricultural techniques and yields. The values obtained are consequently variable as shown in the Tables 2 and 3 , extracted from [4].

TABLE 2

Energy balance and greenhouse gas balance for ethanol produced from wheat

\begin{tabular}{|c|c|c|c|c|c|c|}
\hline \multirow{3}{*}{ Growing region } & \multicolumn{6}{|c|}{ Wheat } \\
\hline & \multirow[t]{2}{*}{ UK } & \multicolumn{2}{|c|}{ North France } & \multirow{2}{*}{ UK } & \multirow{2}{*}{$\mathbf{E} \mathbf{U}$} & \multirow{2}{*}{ Average } \\
\hline & & Aver. & Best & & & \\
\hline Ref./case & [5] & {$[6]$} & {$[6]$} & [7] & [8] & \\
\hline Ethanol yield t/ha & 2.2 & 1.9 & 2.5 & 2.5 & 1.7 & 2.1 \\
\hline Energy balance & 1.07 & 0.91 & 0.91 & 0.9 & 1.26 & 1.04 \\
\hline GHG balance & 0.59 & 0.72 & 0.71 & 0.71 & 0.99 & 0.75 \\
\hline
\end{tabular}

TABLE 3

Energy balance and greenhouse gas balance for ethanol produced from beet

\begin{tabular}{l|c|c|c|c}
\hline \multirow{2}{*}{ Growing region } & \multicolumn{4}{|c}{ Beet } \\
\cline { 2 - 3 } & North France & \multirow{2}{*}{ EU } & \multirow{2}{*}{ Average } \\
\cline { 2 - 3 } Ref./case & {$[6]$} & {$[6]$} & {$[8]$} & \\
\hline Ethanol yield t/ha & 5.3 & 6.2 & 3.8 & $\mathbf{4 . 5}$ \\
\hline Energy balance & 0.9 & 0.62 & 0.96 & $\mathbf{0 . 9}$ \\
\hline GHG balance & 0.7 & 0.49 & 0.75 & $\mathbf{0 . 7}$ \\
\hline
\end{tabular}

In these cases, the energy balance is defined as the ratio of the energy required to produce an amount of conventional fuel equivalent to the biofuel to the energy content of the biofuel. A figure of zero indicates a fully renewable fuel while a value of 1.0 indicates that there is no net energy saving.

The GHG balance is defined as the ratio of the net GHG production, expressed as $\mathrm{CO}_{2}$ equivalents, emitted when producing the biofuel to the amount of $\mathrm{CO}_{2}$ equivalents emitted when producing and burning an amount of fossil fuel representing the same end-use energy. A value below one denotes a net reduction in GHG emissions. 
Considering the French case, the most recently published data (ADEME, data from IFP) indicate an energy balance of 0.49 for wheat ethanol and beet ethanol, and some more prospective scenarios foresee balances down to 0.28 for wheat and 0.3 for beet [10].

The calculated energy needs for ethanol production have been shown to be highly variable, according to the raw material, the agricultural techniques and the calculation method. Nevertheless, all these calculations show a positive impact of ethanol in terms of greenhouse gas emissions, due to the fact that ethanol, as far as it is produced from biomass, should have (if ideal) a null $\mathrm{CO}_{2}$ balance (the $\mathrm{CO}_{2}$ emitted during the combustion should be counterbalanced by the $\mathrm{CO}_{2}$ captured by the crop during its growth). In fact, this theoretical and ideal case is never reached, due to energy needs for the agricultural process, the fertilizer uses (nitrogen fertilizers are linked with $\mathrm{N}_{2} \mathrm{O}$ emissions, which have a strong impact on greenhouse effect) and the transformation processes.

\section{KEY PARAMETERS FOR THE DEVELOPMENT OF A DEDICATED ENGINE}

The potential of ethanol in terms of greenhouse gas emissions, when produced from biomass, has been outlined above.

Moreover, ethanol has some very interesting physical and chemical properties that can be turned into benefits with a dedicated engine, provided some technical difficulties are overcome. The following section describes these advantages and disadvantages of ethanol and gives an example of a preliminary development with a small displacement dedicated engine.

\subsection{Ethanol Properties}

The main properties of ethanol are summarized in Table 4 .

TABLE 4

Ethanol physical properties

\begin{tabular}{|c|c|c|c|}
\hline & & Ethanol & Gasoline (typical) \\
\hline Molar mass & $(\mathrm{g} / \mathrm{mol})$ & 46.07 & 102.5 \\
\hline $\mathrm{C}$ & $(\% \mathrm{wt})$ & 52.2 & 86.5 \\
\hline $\mathrm{H}$ & $(\% \mathrm{wt})$ & 13.1 & 13.5 \\
\hline $\mathrm{O}$ & $(\% \mathrm{wt})$ & 34.7 & 0 \\
\hline Density & $\left(\mathrm{kg} / \mathrm{m}^{3}\right)$ & 794 & $735-760$ \\
\hline \multicolumn{2}{|c|}{$\begin{array}{l}\text { Latent heat of vaporization } \\
\qquad(\mathrm{kJ} / \mathrm{kg})\end{array}$} & 854 & 289 \\
\hline Distillation & $\left({ }^{\circ} \mathrm{C}\right)$ & 78.4 & $30-190$ \\
\hline Net heating value & $(\mathrm{kJ} / \mathrm{kg})$ & 26805 & 42690 \\
\hline Net heating value & $(\mathrm{kJ} / \mathrm{l})$ & 21285 & 32020 \\
\hline Stoechiometric rat & & 8.95 & 14.4 \\
\hline RON & & 111 & 95 \\
\hline MON & & 92 & 85 \\
\hline
\end{tabular}

This table shows that ethanol has some interesting properties to be used as a fuel for spark-ignition engines:

- A very high octane number, which induces a strong resistance to knock and consequently the ability to optimize the engine (compression ratio, spark-advance).

- A density close to the gasoline one.

- The presence of oxygen in the formula, which can provide a more homogeneous fuel/air mixing and consequently a decrease in unburned or partially burned molecule emissions ( $\mathrm{HC}$ and $\mathrm{CO}$ ).

- A high latent heat of vaporization enabling a "cooling effect" of air and consequently can enhance the filling efficiency.

On the opposite, some disadvantages have to be considered:

- The oxygen included in the molecule (30\%wt) induces an increase in the fuel volumetric consumption.

- The high latent heat of vaporization can induce running difficulties in cold conditions, especially cold start.

- Ethanol leads to azeotropes with light hydrocarbon fractions and can lead to volatility issues.

- Ethanol is miscible with water, which can cause demixing issues when blended with hydrocarbons.

- The high oxygen content of ethanol and its ability to oxidize into acetic acid induce compatibility issues with some materials used in the engine, such as metals or polymers.

- Ethanol combustion in engines induces aldehydes emissions, which can have a negative impact on health.

These points are further detailed in the following sections.

\subsection{Octane Number}

Ethanol is characterized by high octane numbers (RON and MON). A dedicated engine will consequently be less knock sensitive and its compression ratio can be increased, to enhance the engine efficiency.

This physical property is particularly useful to reduce $\mathrm{CO}_{2}$ emissions of spark-ignition engines: yet, one of the most promising ways seems to be the downsizing of engines, with the generalization of small displacement turbocharged engines. Whereas these engines could be generally highly knock sensitive, a substantial improvement could be brought by the use of high octane fuels.

A typical correlation that is used for compression ratio calculation gives a value of $1 \mathrm{CR}$ point increase for about 5 points octane [12]. When ethanol is used on a typical sparkignition engine ( $C R=9, R O N$ 95), the compression ratio could go up to 13-14, inducing a substantial thermal efficiency increase. So far, most of the developments on dedicated engines selected a compression ratio around 12-12.5, because of they used E85 (85\% ethanol mixture) instead of pure ethanol (cold start driveability improvement, see below). Moreover, such high octane numbers are subject to a high uncertainty in their measurements, and also in their 
physical meanings. Indeed, the ASTM D2699 method for RON values higher than 100 is based on the comparison of the tested fuel with leaded isooctane. One should assume that, even if those 2 fuels may behave the same way in a CFR engine, their radically different physical and chemical properties can induce different behaviors in real engines.

\subsection{Oxygen Content}

The oxygen content in ethanol is around $35 \%$ wt. The mass heating value of ethanol is consequently lower than the gasoline one (respectively $27 \mathrm{MJ} / \mathrm{kg}$ and $42.7 \mathrm{MJ} / \mathrm{kg}$ ). Ethanol higher density tends to reduce the difference in volumic heating values, but a significant difference remains. Besides, another parameter has to be considered: the specific energy, which is the energy released for each unit mass of air consumed in stochiometric conditions. It corresponds to the ratio (heating value/air-fuel ratio). This ratio is around 3 for ethanol and 2.9 for a typical gasoline. Indeed, the oxygen in ethanol reduces the stochiometric ratio, i.e. the mass of air which is needed to get the total combustion of a given quantity of fuel. As shown in Table 4, this stochiometric ratio is around 9 for ethanol and 14 for gasoline.

As a consequence of this difference, if the engine efficiency remains similar for gasoline and ethanol, the fuel volumetric consumption is inevitably increased when running with ethanol.

Moreover, the high oxygen content of ethanol has some significant positive aspects, especially when pollutant emissions are considered. As stated above, the use of oxygenated compounds can lead to a more homogeneous combustion by bringing oxygen in the core of the fuel, where the oxygen brought by air can never arrive. A decrease in $\mathrm{CO}$ and $\mathrm{HC}$ emissions can consequently be measured, but the reduction level varies according to the vehicle type and technology. The impact on $\mathrm{HC}$ emissions is also important, but is highly variable because of the high number of parameters implied:

- decrease in air/fuel local heterogeneity (decrease in HC emissions);

- volatility increase (increase in evaporation HC emissions);

- decrease in HC emissions when ethanol is used as a substitution for other high octane molecules such as aromatics (HC precursors).

\subsection{Volatility}

Ethanol by itself has a moderate volatility. Table 4 shows that its boiling point is relatively high $\left(78^{\circ} \mathrm{C}\right)$ in comparison with gasoline initial distillation point. Moreover, the vapor pressure, calculated according to Antoine's law, is low for ethanol in comparison with the light fractions of the fuel (Fig. 2).

Nevertheless, another physical property must be remembered: ethanol can strongly interact with some hydrocarbons, leading to the formation of azeotropes. Azeotropes are defined as any liquid mixture having constant minimum and maximum boiling points and distilling off without decomposition and in a fixed ratio. Their main characteristic is to have a boiling point radically different from the boiling points of each component on its own, and consequently a different vapor pressure at a given temperature. Ethanol azeotropes have boiling points lower than the initial boiling points of their components.

For instance, ethanol and $n$-pentane can give an azeotrope which boiling point is $34^{\circ} \mathrm{C}$, lower than the respective boiling points of ethanol $\left(76^{\circ} \mathrm{C}\right)$ and $n$-pentane $\left(36^{\circ} \mathrm{C}\right)$. The Table 5 summarizes the most common azeotropes formed with ethanol.

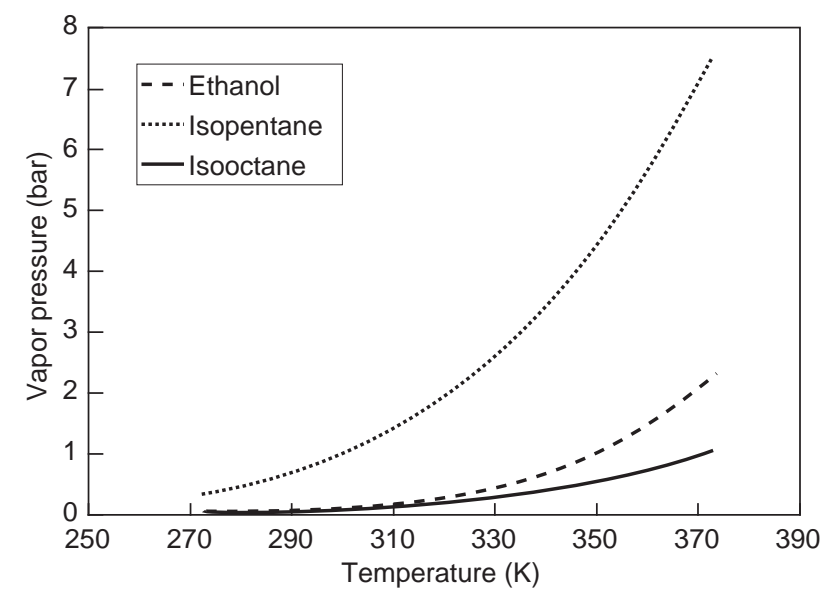

Figure 2

Vapor pressure of ethanol. Comparison with typical gasoline components

TABLE 5

Common ethanol azeotropes characteristics [13]

\begin{tabular}{l|c|c|c}
\hline Molecule & $\begin{array}{c}\text { Pure boiling } \\
\text { point }\left({ }^{\circ} \mathbf{C}\right)\end{array}$ & $\begin{array}{c}\text { Azeotrope boiling } \\
\text { point }\left({ }^{\circ} \mathbf{C}\right) \\
\text { with ethanol }\end{array}$ & $\begin{array}{c}\text { Composition } \\
\text { of the azeotrope } \\
\text { (\%wt ethanol) }\end{array}$ \\
\hline$n$-pentane & 36 & 34 & 5 \\
$n$-hexane & 69 & 59 & 21 \\
benzene & 80 & 68 & 32 \\
cyclohexane & 81 & 65 & 29.2 \\
toluene & 111 & 77 & 68 \\
$n$-octane & 126 & 77 & 88 \\
\hline
\end{tabular}


The impact of these azeotropes is important when blending ethanol with fuels, by leading to an increased vapor pressure.

Of course, this phenomenon is avoided when pure ethanol is used. Nevertheless, as stated above, pure ethanol has a distillation point of $78.4^{\circ} \mathrm{C}$, characteristic associated with an important latent heat of vaporization, inducing cold start difficulties. To avoid this phenomenon, E85 (ethanol blended with $15 \%$ light hydrocarbons) instead of pure ethanol is a commonly used solution. Moreover, as presented above, most countries prefer to use low ethanol concentrations (lower than $10 \%$ ) in fuels. Azeotrope formation can have an important impact on these kinds of fuels: if the fuel volatility is not correctly controlled, adding ethanol can induce a strong increase in evaporative losses. For refiners, this physical phenomenon means that "plash blending" is difficult with ethanol: ethanol can only be added to selected (low volatility) base fuel.

\subsection{Water Tolerance}

Ethanol and water are miscible in any proportions, while hydrocarbons and ethanol are not miscible. With conventional gasolines containing hydrocarbons, or ethers, the presence of water in the fuel is not a serious concern. In fact, up to $50 \mathrm{ppm}$ at ambient temperature (of course this value depends of the gasoline chemical composition), water remains completely soluble. Over this level, water separates without affecting the hydrocarbon portion and the water layer can be extracted if necessary.

On the opposite, in ethanol blends, traces of water can induce a total demixing into two phases: one phase is a mixture of ethanol and water and the other phase contains the hydrocarbons. Demixing traces are not acceptable.

Moreover, whereas ethanol can be used as an "octane enhancer" in the fuels, the demixing between the base fuel and ethanol, in presence of water leads to a decrease in the octane number of the base fuel, which could seriously damage the engine.

To avoid this phenomenon, some methods can be used, such as the use of "cosolvents" (for instance TBA (tert-butyl alcohol) in the 1980's in the United States) or a careful check of fuel storing tanks water tightness.

Another way to avoid this phenomenon could be the use of pure ethanol [16]. Indeed, water is miscible in ethanol and consequently no demixion phenomenon can occur. Nevertheless, the already mentioned issues linked to engine cold start remain.

\subsection{Cold Start}

Pure ethanol has a moderate volatility. Its high boiling point $\left(78^{\circ} \mathrm{C}\right)$ induces difficulties of vaporization in ambient or cold conditions.
Moreover, as it has been outlined previously, ethanol has a very high latent heat of vaporization (3 times higher than typical gasoline). This property induces driveability difficulties: the vaporization of ethanol in cold conditions needs a lot of energy and consequently induces a cooling effect [17].

To lower this phenomenon, some technical solutions can be applied. The most frequently used solution is to use E85 ( $85 \%$ ethanol) instead of pure ethanol. The addition of $15 \%$ light hydrocarbon fraction in ethanol induces a strong increase in volatility and consequently an easier engine start. Nevertheless, this modification has to be made carefully to avoid the loss of some of the ethanol advantages (octane number, low $\mathrm{HC}$ and $\mathrm{CO}$ emissions).

Other solutions have been studied, especially in Brazil. Among these, the most widely spread are the heating of the fuel injection system (and especially the fuel-rail) or the use of a second tank, filled with highly volatile gasoline, to run the engine for a few seconds before switching to ethanol.

\subsection{Material Compatibility}

\subsubsection{Polymers}

Ethanol induces the swelling and weakening of rubber components, due to the absorption of fuel into rubber. Once absorbed into rubber, the oxygen of the alcohol breaks the rubber's carbon-carbon double bonds. The consequence of swelling and weakening can be a fuel leak that can endanger car users [17].

Swelling and component breakdown can all be solved by the use of compatible materials such as highly fluorinated rubbers $\left(\right.$ Viton $\left.^{\circledR}\right)$ [18]. Nylon can also be resistant, but only at low temperature $\left(<30^{\circ} \mathrm{C}\right)$ [19]. This polymer can consequently be used for intake fuel line, provided the fuel temperature remains low.

\subsubsection{Galvanic Corrosion}

Galvanic corrosion happens when 2 metals are in contact, generally through a conducting electrolyte. For instance, stainless steel and aluminum can undergo galvanic corrosion when placed side by side.

Typical fuels (with no additives) have an electrical conductivity between $10^{-8}$ to $10^{-6} \mu \mathrm{S} / \mathrm{cm}$. Ethanol electric conductivity is $1.3510^{-3} \mu \mathrm{S} / \mathrm{cm}$. Moreover, the oxidation of ethanol into acetic acid induces a rapid increase in electrical conductivity ( $41 \mu \mathrm{S} / \mathrm{cm}$ for a $0.1 \mathrm{M}$ acetic acid solution). The presence of acetic acid can consequently enhance galvanic corrosion and chemical attack. The metals recommended for use with ethanol include carbon steel, stainless steel and bronze. Metals such as magnesium, zinc casings, brass and copper are not recommended [14].

The previous paragraph assumes that ethanol is "dry", which means it contains no water. Yet, as water is miscible in 
ethanol, ethanol with very high water content has been found in the past (up to $5 \% \mathrm{vol}$ ), with ion concentrations that make it much more aggressive than pure ethanol [15]. The use of anhydrous ethanol is consequently mandatory to avoid engine corrosion. This is the most important limitation to ethanol development, as far as fuel logistic and storage are concerned.

\section{PRELIMINARY DEVELOPMENT OF A DEDICATED ENGINE}

This section describes the preliminary development of a small displacement dedicated engine. Indeed, if some changes have been done on the engine, it has not been fully optimized. Nevertheless, these results show the potentiality of ethanol.

\subsection{Engine Initial Characteristics}

The selected engine is a small turbocharged engine. Its main characteristics are described in Table 6.

TABLE 6

Engine initial characteristics

\begin{tabular}{l|l}
\hline Engine characteristic & Value \\
\hline Cylinder/valves & 3 cylinders/6 valves \\
Displacement & $599 \mathrm{~cm}^{3}$ \\
Compression ratio & $9.5: 1$ \\
Bore & $63.5 \mathrm{~mm}$ \\
Stroke & $63 \mathrm{~mm}$ \\
\hline
\end{tabular}

This engine has been fully characterized, with a RON95 EN228 gasoline, then modified as described below.

\subsection{Engine Modifications}

To run with ethanol, the following modifications have been done:

- increase in engine compression ratio;

- modification of engine fuel system;

- modification of cylinder head.

\subsubsection{Compression Ratio}

The compression ratio has been increased from 9.5 to 12.5 by modifying the piston geometry. A new piston has been designed and produced. Piston rings have also been modified to be more resistant.

The new compression ratio (12.5) was selected to optimize engine efficiency. A higher compression ratio could have been used, but tests led on natural gas engines showed that this intermediate compression ratio is a reasonable compromise between engine efficiency and mechanical constraints.

Moreover, to ensure a good resistance to pressure, the connecting rods have also been redesigned with a target of 110 bar of maximum pressure resistance. This new connecting rod design is close to diesel connecting rods.

Both pistons and connecting rods were heavier than original parts. As the engine is a 3-cylinder, the crankshaft had to be modified to be reequilibrated.

\subsubsection{Engine Fuel System}

Ethanol contains approximately $35 \%$ oxygen, which does not participate to the heat release during combustion. To maintain high and full load performances, the injection system had to be modified in a way to increase the injection flow by $35 \%$. To reach this objective, the injector hole diameter had to be enlarged by more than $16 \%$.

The maximum fuel flow of the initial engine was assumed to be lower than $4 \mathrm{~kg} / \mathrm{h}$, which means around $66 \mathrm{~g} / \mathrm{min}$. With a maximum ethanol flow $35 \%$ higher, ethanol injectors must have a static flow of $90 \mathrm{~g} / \mathrm{min}$. Bosch LPG injectors were selected, with a static flow around $100 \mathrm{~g} / \mathrm{min}$, in line with the needs of this engine. The components of these injectors were tested according to their chemical resistance to ethanol and have shown a reasonably good behavior.

\subsubsection{Cylinder Head}

Some previous tests had shown a rather poor resistance of exhaust valves and spark plug to ethanol. Indeed, due to a lack of heavy fractions, ethanol does not induce a correct cooling of the exhaust parts and thus could lead to valves fusion on very high speed/high load running conditions. Moreover, very high temperatures can lead to fusion of the spark-plug electrodes.

To avoid this phenomenon, the valves were changed to bimaterial "nimonic" valves (nickel-chromium alloy with good mechanical properties and oxidation resistance at high temperatures). The spark plugs have also been changed to more temperature resistant ones.

\subsection{Results}

\subsubsection{Full Load}

The full load curve obtained with the gasoline and the ethanol versions of the engine are presented in Figure 3.

Ethanol enables a maximum torque of $95 \mathrm{Nm}$ at $3500 \mathrm{rpm}$, while the gasoline engine is limited to $82 \mathrm{Nm}(+15 \%)$. The maximum power is consequently increased from $39 \mathrm{~kW}$ for gasoline $(65 \mathrm{~kW} / \mathrm{l})$ to $45 \mathrm{~kW}$ for ethanol $(75 \mathrm{~kW} / \mathrm{l})$. This full load curve is limited by the exhaust temperature (turbine thermal resistance) and the maximum compressor efficiency (waste gate closed). 


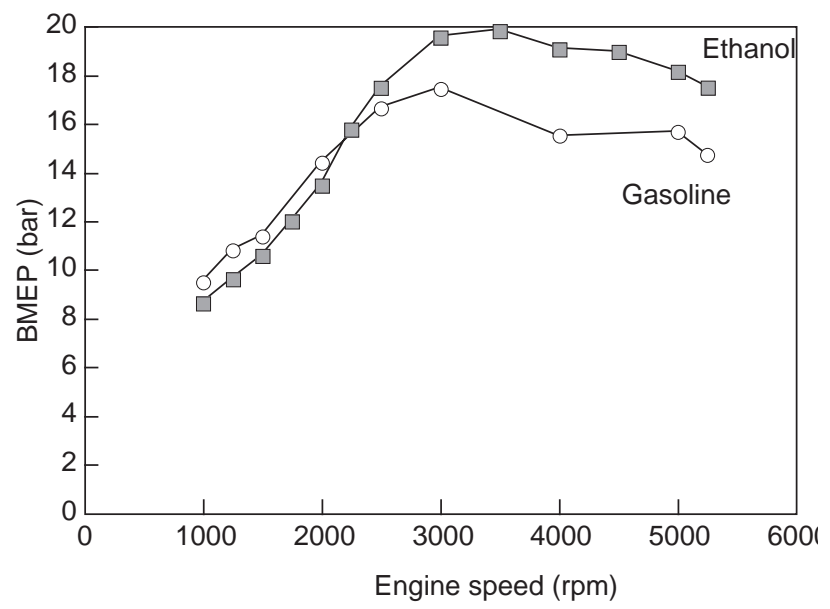

Figure 3

Full load curve.

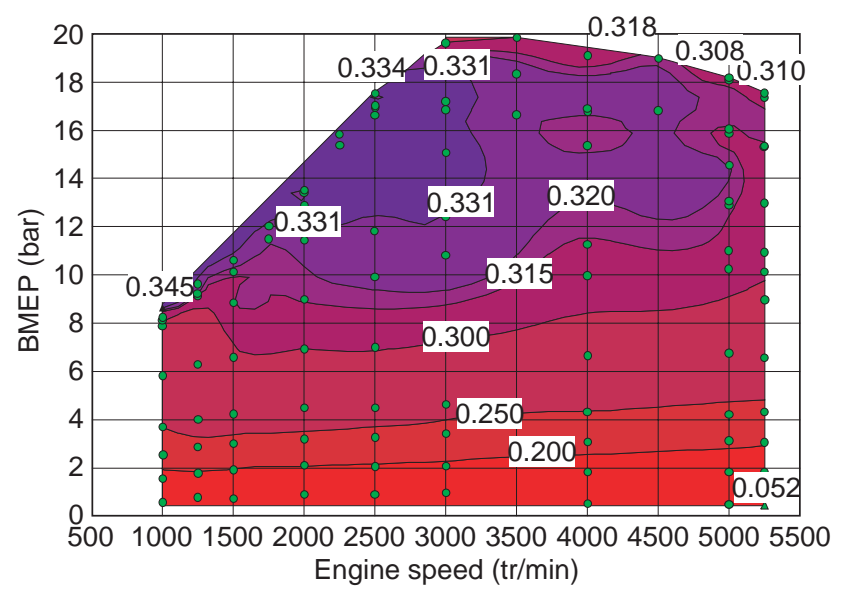

Figure 5

Engine global efficiency-ethanol.

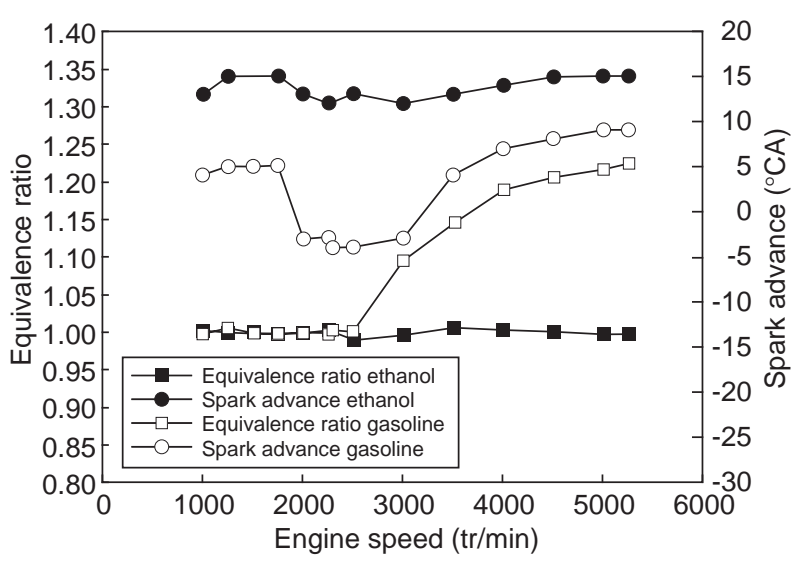

Figure 4

Full load results: spark advance and equivalence ratio (isoperformances).

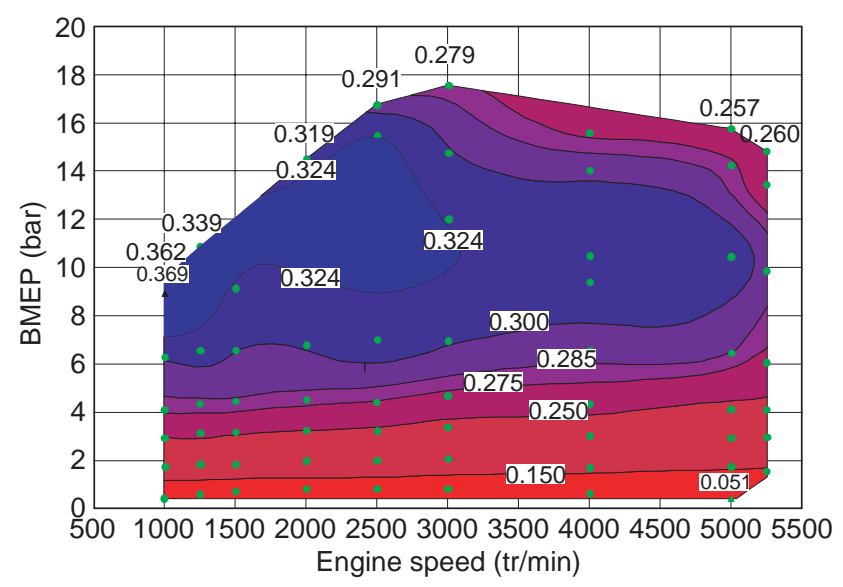

Figure 6

Engine global efficiency-gasoline.
It has to be outlined that the turbo-charging system was not changed and may not be suitable for ethanol. For instance, the low end torque is slightly lower with ethanol than with gasoline, which could be avoided with a more optimized compressor and an adaptation of the turbine. The study of the cylinder maximum pressure shows that an increase potential remains, as the maximum recorded pressure with ethanol is 95 bar (the engine was modified to reach 110 bar cylinder pressure).

Moreover, the full load curve with ethanol has been obtained in stoichiometric running conditions, with an exhaust temperature (before turbine) under $950^{\circ} \mathrm{C}$. Figure 4 presents the equivalence ratio and spark advance for gasoline (full load curve) and for ethanol (same performance). The comparison of these curves shows that the spark advance can be increased by 5 to $15 \mathrm{CA}$ and that no mixture enrichment is necessary when using ethanol.

This figure shows that ethanol, even without taking the "biofuel" aspect into account, can provide substantial benefits for low $\mathrm{CO}_{2}$ engines (small displacement, high compression ratio, turbocharged). 


\subsubsection{Engine Efficiency}

The engine global efficiency was calculated according to the ratio released energy/maximum theoretical energy. The maximum theoretical energy was calculated according to the BSFC and the fuel net heating value $(42800 \mathrm{~kJ} / \mathrm{kg}$ for gasoline, $26800 \mathrm{~kJ} / \mathrm{kg}$ for ethanol). The results obtained for this calculation are presented in the Figures 5 to 7 .

At low speed/low load running conditions, the efficiency is higher for gasoline than for ethanol but, at high speed / high load, the impacts of the increased compression rate and of the stochiometric running are important and give the advantage to ethanol, as shown in Figure 7.

\subsection{3 $\mathrm{CO}_{2}$ Emissions}

In the frame of its commitment with European Union, ACEA has claimed its will to decrease $\mathrm{CO}_{2}$ emissions of the fleet down to $140 \mathrm{~g} / \mathrm{km}$ in 2008. Thus, $\mathrm{CO}_{2}$ emissions became one of the key parameters when designing an engine. Ethanol, as a biofuel, has an important potential in terms of lowering $\mathrm{CO}_{2}$ emissions "from well to tank". Nevertheless, its efficiency in the engine has to be checked in order to get the $\mathrm{CO}_{2}$ emissions over the full path.

The $\mathrm{CO}_{2}$ emissions of gasoline and ethanol engine are presented in the Figures 8 and 9.

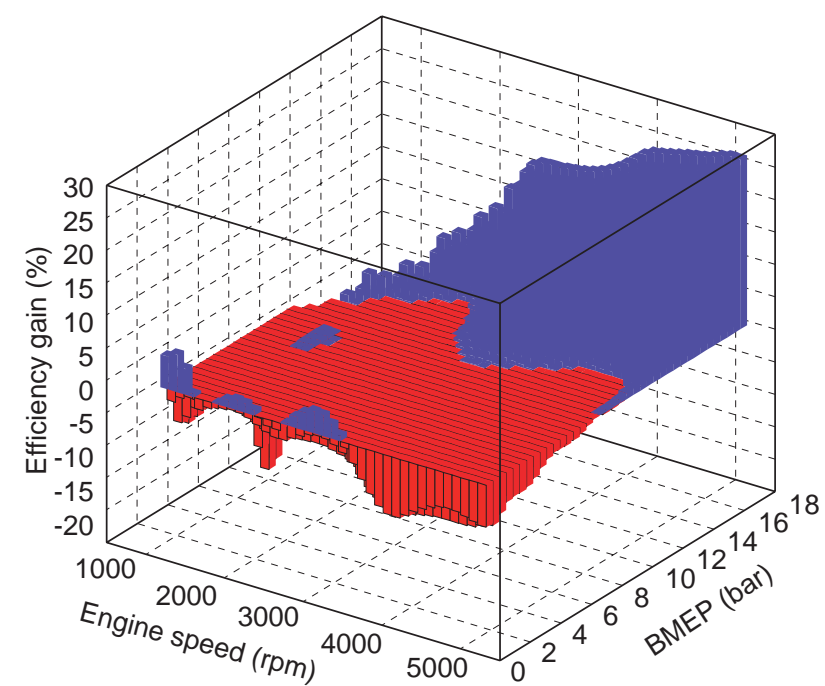

Figure 7

Engine efficiency gain when running with ethanol.

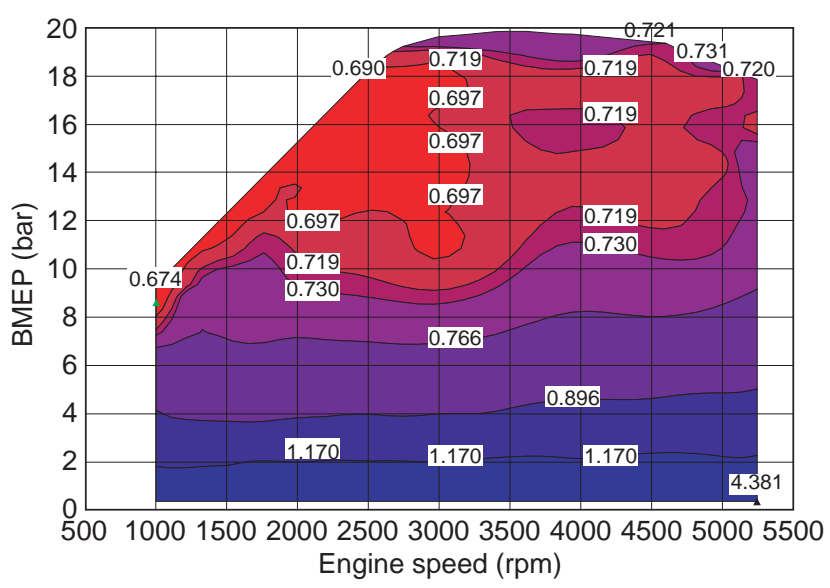

Figure 9

$\mathrm{CO}_{2}$ emissions $(\mathrm{kg} / \mathrm{kWh}$-ethanol engine.

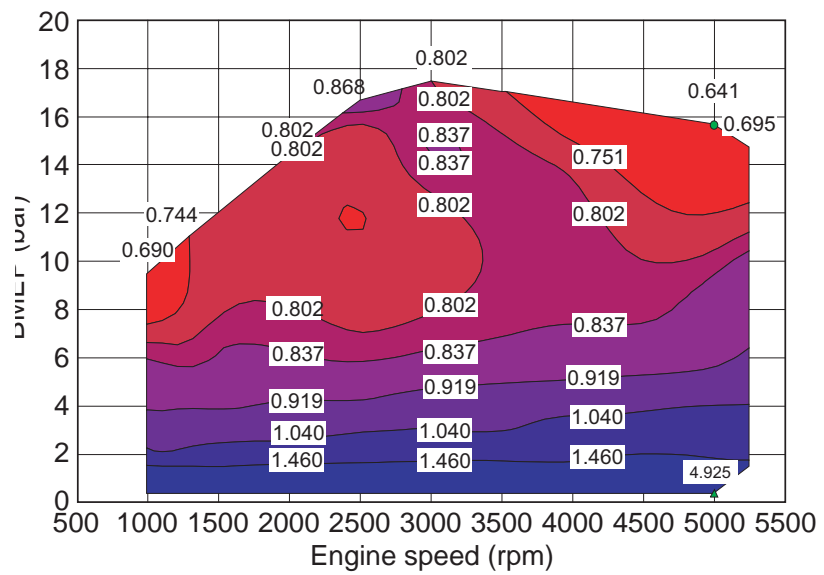

Figure 8

$\mathrm{CO}_{2}$ emissions ( $\left.\mathrm{kg} / \mathrm{kWh}\right)$-gasoline engine.

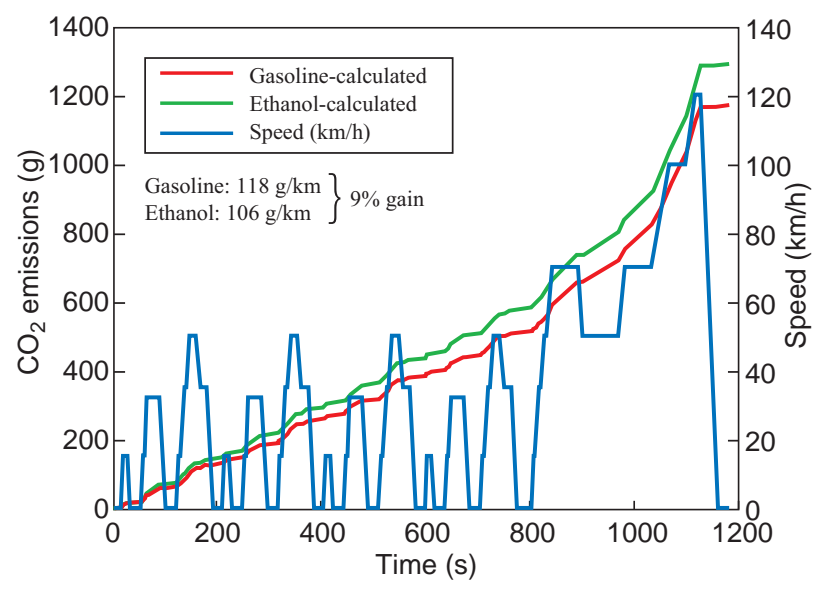

Figure 10

Calculation of $\mathrm{CO}_{2}$ emissions on the NEDC cycle. 


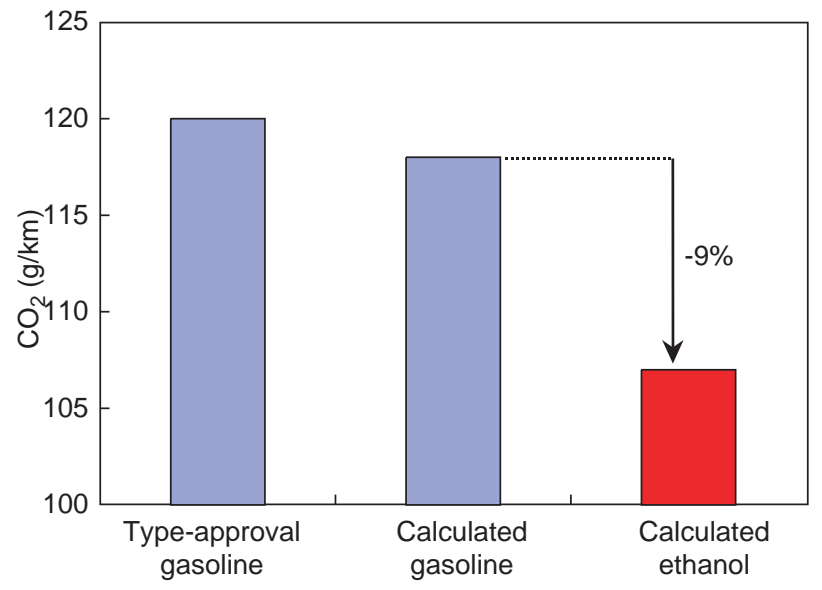

Figure 11

Summary of global $\mathrm{CO}_{2}$ emission on the NEDC cycle.

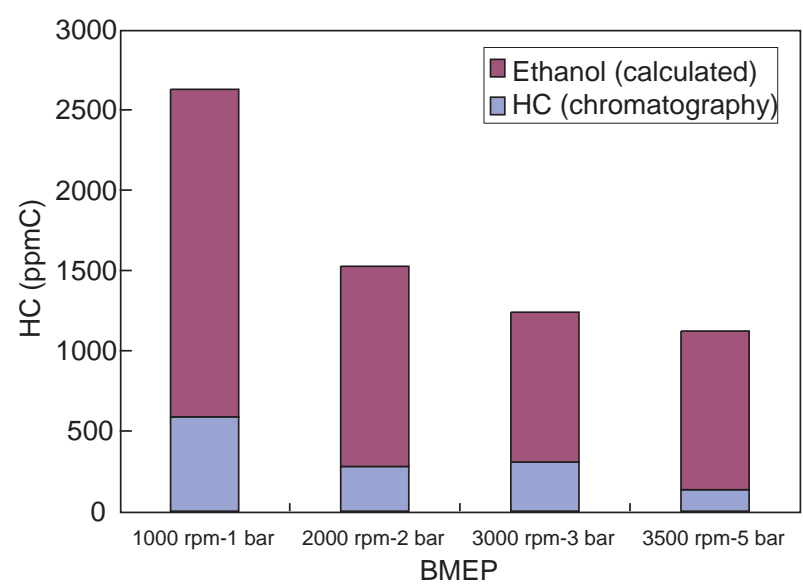

Figure 12

Ethanol and $\mathrm{HC}$ emissions before catalyst.
This shows the significant benefits of ethanol on $\mathrm{CO}_{2}$ emissions. An important reduction can be obtained (up to $20 \%$ ), which can be explained by the high $\mathrm{H} / \mathrm{C}$ ratio of ethanol (3, against 1.8 for typical gasoline). For instance, for a $2000 \mathrm{rpm}-2$ bar BMEP, $\mathrm{CO}_{2}$ emissions are $1.22 \mathrm{~kg} / \mathrm{kWh}$ for gasoline and $1.13 \mathrm{~g} / \mathrm{kWh}$ for ethanol $(-7.4 \%)$.

To get an evaluation of the benefits on a dedicated vehicle, some simulations have been led using Amesim ${ }^{\circledR}$ [20] with the values recorded on bench tests. $\mathrm{CO}_{2}$ emissions were calculated on the standard European type-approval driving cycle. The results are summarized Figures 10 and 11.

This data processing shows good results for gasoline engine in comparison with type-approval value $(120 \mathrm{~g} / \mathrm{km})$. The calculation on ethanol engine data shows a $9 \%$ reduction in $\mathrm{CO}_{2}$ emissions.

Besides, this assessment has been realized without any change in the vehicle design, and especially with the same gearbox ratios. As demonstrated above, ethanol allows an increase in engine maximum power and torque, enabling further $\mathrm{CO}_{2}$ reduction via a gearbox and transmission optimization.

\subsubsection{Pollutant Emissions}

$\mathrm{HC}$ emissions are difficult to measure accurately with the flame ionization detector typically used for engine pollutant emissions measurement. Indeed, the response factor for oxygenated compounds in these analyzers is low (for instance 1.8 instead of 2 for ethanol, which means that less than $90 \%$ of ethanol emissions are analyzed). Assuming that most of the $\mathrm{HC}$ emissions are made up of unburned hydrocarbons, the total $\mathrm{HC}$ emission level can be corrected by the response factor of ethanol. The value obtained for $\mathrm{HC}$ emissions in ethanol configuration is then a maximum estimate (considering that $\mathrm{HC}$ emissions are exclusively made up of ethanol).
To minimize this bias and obtain a more accurate $\mathrm{HC}$ emission characterization, chromatographic analyses have been achieved, analyzing the chemical species in $\mathrm{HC}$ emissions $\left(\mathrm{C}_{1}\right.$ $\mathrm{C}_{8}$ ). These analyses have shown that, as far as nonoxygenated hydrocarbons are concerned, ethylene represents more than $50 \%$ of HC emissions. This molecule comes directly from ethanol decomposition as shown in the Figure 13.<smiles>CC=CC</smiles>

Figure 13

Ethanol decomposition simplified mechanism.

The comparison of the total $\mathrm{HC}$ emission measured with ionization detector and chromatography enables an evaluation of ethanol emissions. Indeed, for the 4 tested running points, the $\mathrm{HC}$ emissions measured by chromatography can be compared to the total $\mathrm{HC}$ emissions and the total amount of unburned ethanol can be calculated, as shown in Figure 12. This calculation assumes that ethanol (or light aldehydes) is the only component of all $\mathrm{HC}$ that are not analyzed here in line by gas chromatography.

As far as $\mathrm{CO}$ emissions are concerned, ethanol brings a real gain. At low engine speeds, $\mathrm{CO}$ emissions with ethanol are approximately reduced to the half in comparison with gasoline. At very high load running conditions, ethanol induces also very low $\mathrm{CO}$ emissions in comparison with gasoline, because of its low exhaust temperature, enabling to run the full load curve without any mixture enrichment. For 
instance, at the $5250 \mathrm{rpm}$-WOT running point, $\mathrm{CO}$ emissions before catalyst are divided by 6 when running with ethanol, despite the higher torque and power obtained with ethanol.

NOx emissions are less impacted by the use of ethanol, and the results are highly dependant on the running conditions: if for most of the running points, NOx emissions are similar with gasoline or ethanol, some significant differences can be observed for high speed running points.

- At low load, NOx emissions with ethanol are lower than with gasoline, due to differences in the latent heat of vaporization and in the combustion speed.

- At high load, the mixture enrichment in gasoline induces a decrease in the combustion temperature and consequently in NOx emissions. As mixture enrichment is not needed with ethanol, NOx emissions are higher. On the other hand, the low exhaust temperatures when using ethanol enable a stoichiometric running among the whole running range, and makes it possible to use a 3-ways catalyst to reduce NOx emissions, even at full load.

\subsection{Further Optimization}

These results show the true benefits brought by ethanol with only a little optimization of the engine: the increased compression ratio induces an important benefit in terms of engine efficiency and $\mathrm{CO}_{2}$ emissions. Still, some points have to be further studied to get a fully optimized engine:

- The tested engine was a PFI engine. To get full benefits from ethanol high latent heat of vaporization via the "cooling effect" (increase in filling efficiency due to the intake air cooling when ethanol is vaporized), a direct injection engine should be used.

- No change was done on the supercharging system. The optimization of this part of the engine could lead to an increased low-end torque.

- Some critical points, such as cold start management or lubricant compatibility, have to be further studied to obtain a fully useable engine.

- Aldehyde emissions have to be considered. As we have worked on engine-out emissions and as even aldehydes have been measured, it is not realistic to conclude on these pollutants without exhaust gas after-treatment.

- The catalyst adaptation has to be checked. Indeed, the low exhaust temperature found with ethanol can induce catalyst light-off difficulties.

\section{CONCLUSION}

In the context of the objective of reducing greenhouse gas emissions, it is worth closely evaluating the use of biofuels in internal combustion engines.
First, ethanol characteristics when used pure as fuel in a dedicated engine were reviewed, to determine the balance between its main advantages and disadvantages. Later, after having summarized the main production processes and their relative efficiencies, the main physical properties of ethanol have been analyzed in regard to their positive or negative impact on engine running. Finally, the results obtained on a dedicated engine are presented. The main conclusions are:

- The high diversity of the production paths and feedstock induces highly variable ethanol energy efficiency calculations. According to the raw material (sugar beet, corn, wheat, etc.), to the agricultural yield and to the transformation process efficiency, the energy balance (energy used/energy produced) has been shown to vary from 0.3 to 1.6

- In a dedicated engine, ethanol-fuel has many advantages, such as its high octane number or its high latent heat of vaporization. These advantages can be valorized in a dedicated engine, provided that some issues are solved (material compatibility, water tolerance, volatility). This ethanolfuel can bring substantial benefits when used in low $\mathrm{CO}_{2}$ engines, such as small displacement turbocharged ones.

- A preliminary optimization of a small displacement turbocharged engine has confirmed the potential benefit of this fuel, with an increase in engine efficiency and a decrease in $\mathrm{CO}_{2}$ emissions. Some calculation using vehicle simulation models $\left(\right.$ Amesim $\left.^{\circledR}\right)$ have shown a net reduction of $9 \%$ in $\mathrm{CO}_{2}$ emissions on the NEDC cycle. Moreover, a significant reduction in $\mathrm{CO}$ emissions has been noticed.

- Some further optimizations such as cold start strategies optimized gearbox or dedicated turbo charging system should be foreseen to get a fully useable engine.

- Ethanol-fuel can truly induce a $\mathrm{CO}_{2}$ emission reduction in dedicated engines. Further, as this fuel can be produced from biomass, its "well to wheel" $\mathrm{CO}_{2}$ balance appears to stand at a very interesting level.

\section{ACKNOWLEDGEMENTS}

The authors would like to thank $\mathrm{Ph}$. Turbin who performed the engines tests and Ph. Kopeckny for the vehicle calculations.

\section{REFERENCES}

1 Office of Coal, Nuclear, Electric and Alternate Fuels (1994) Alternatives to Transportation Fuels - An Overview, Energy Information Administration.

2 Klasson, K.T., Elmore, B.B., Vega, J.L., Ackerson, M.D., Clausen, E.C. and Gaddy, J.L. (1990) Biological Production of Liquid and Gaseous Fuels from Synthesis Gas. Applied Biochemistry and Bioengineering, 24/25, 857-873.

3 USDA/NASS (2004) Track Records, United States Crop Production, 1866 to Date. 
4 Energy and Greenhouse Gas Balance of Biofuels for Europe an Update (2002) Concawe Report No. 2/02.

5 Gover, M.P., Collings, S.A., Hitchcock, G.S., Moon, D.P. and Wilkins, G.T. (1996) Alternative Road Transport Fuels - A Preliminary Life-cycle study for the UK, ETSU R92, London, HMSO.

6 Levy, R.H.(1993) Les biocarburants. Report to the French Government Based on Figures from the Commission consultative pour la production des carburants de substitution.

7 Richards, I.R. (2000) Energy balances in the growth of oilseed rape for biodiesel and of wheat for bioethanol. Report for the British Association of Bio Fuels and Oils (BABFO), Ipswich, Levington Agriculture Ltd.

8 EU (1994) Application of biologically derived products as fuels or additives in combustion engines. Publication No. EUR 15647 EN, Directorate-General XII Science, Research and Development.

9 http://www.usda.gov/wps/portal/usdahome

10 ADEME (2002) Ecobilan, DIREM, Bilans énergetiques et gaz à effet de serre des filières de production de biocarburants en France, note de synthèse.

11 Pimentel, D. (2001) The Limits of biomass utilization. In: The Encyclopedia of Physical Science and Technology. Academic Press., NY.
12 Searle, G.R. (1995) Octane Quality and Knock. In: Motor Gasoline, College of Petroleum and Energy Studies, Oxford, Royal Society of Chemistry publication.

13 CRC (1993) Handbook of Chemistry and Physics. 74th ed., CRC Press, Boca Raton, Fla.

14 Bechtold, R.L. (1997) Alternative Fuels Handbook. SAE Press, ISBN 0-7680-0052-1.

15 Mueller Associates, Inc. Status of Alcohol Fuels Utilization Technology for Highway Transportation: a 1986 Perspective, Spark-Ignition Engines (1985) Report $N^{\circ}$ ORNL/Sub/85-22007/4, National Technical Information Service,Springfield, Va.

16 Alternative Fuel in the Automotive Market (1995) Concawe Report 2/95.

17 Hammel-Smith, C., Fang J., Powders, M. and Aabakken J. (2002) Issues Associated with the Use of Higher Ethanol Blends (E17-E24). NREL Technical Report NREL/PP-510-32206.

18 Nersasian, A. (1980) The Vol. Increase of Fuel Handling Rubbers in Gasoline/Alcohol Blends. SAE Paper No. 800789.

19 Dunn, J.R. and Pfisterer, H.A. (1980) Resistance of NBRBased Fuel Hose Tube to Fuel-Alcohol Blends. SAE Paper No. 800856.

$20 \mathrm{http} / / / \mathrm{www}$. amesim.com

Final manuscript received in December 2004 or distributed for profit or commercial advantage and that copies bear this notice and the full citation on the first page. Copyrights for components of this work owned by others than IFP must be honored. Abstracting with credit is permitted. To copy otherwise, to republish, to post on servers, or to redistribute to lists, requires prior specific permission and/or a fee. Request permission from Documentation, Institut français du pétrole, fax. +33147527078 , or revueogst@ifp.fr. 